\title{
Seroprevalence of Toxoplasma gondii in slaughtered horses and donkeys in Liaoning province, northeastern China
}

\author{
Na Yang ${ }^{1}$, Ming-Yang Mu' ${ }^{1}$ Gao-ming Yuan ${ }^{1}$, Guo-xin Zhang ${ }^{1}$, Hong-Kui Li ${ }^{2}$ and Jian-Bin He ${ }^{\text {** }}$
}

\begin{abstract}
Background: Toxoplasma gondii is an important zoonotic pathogen infecting humans and almost all warm-blooded animals. The most common sources of human infection are ingestion of tissue cysts in raw or undercooked meat. However, limited information is available about T. gondii infection in horses and donkeys in China. In the present study, we report the seroprevalence of T. gondii infection in horses and donkeys in Liaoning province, northeastern China.
\end{abstract}

Methods: Serum samples were collected from 711 and 738 slaughtered horses and donkeys, respectively, in 13 regions of Liaoning province. The modified agglutination test (MAT) was used to test the specific antibodies to T. gondii.

Results: In this study, 178 of 711 (25.0\%) horses were seropositive for T. gondii with titers of 1:25 in 81, 1:50 in 62, 1:100 in 33 , and 1:200 in 2, and seroprevalence of T. gondii infection from 13 regions ranged from 8.2\% to 37.0\%. Antibodies to T. gondii were found in 174 of 738 (23.6\%) donkeys with titers of 1:25 in 66, 1:50 in 54, 1:100 in 49, and 1:200 in 5, and seroprevalence varied in 13 different regions, ranging from $9.1 \%$ to $32.6 \%$.

Conclusions: The results of the present study indicated that the rate of infection with $T$. gondii in horses and donkeys is a little high in Liaoning province, northeastern China in comparison to other surveys in China, which suggests that consumption of horse and donkey meat in this area may represent a potential source for human infection with $T$. gondii.

Keywords: Toxoplasma gondii, Seroprevalence, Horse, Donkey, MAT

\section{Background}

Toxoplasma gondii parasites are obligate intracellular apicomplexans that can infect virtually all warm-blooded animals; felids are definitive hosts. The most common sources of human infection are ingestion of tissue cysts in raw or undercooked meat or of food or water contaminated with oocysts shed by felids and transplacental transmission [1]. T. gondii infection may cause serious disease in pregnant women and immunocompromised patients, such as AIDS patients and organ transplant recipients [2-6].

Meat from birds and warm-blooded animals traditionally has been considered a major source of $T$. gondii infection [7]. Viable parasites have been isolated from the meat

\footnotetext{
*Correspondence: hejianbinjs@163.com

${ }^{1}$ College of Animal Science and Veterinary Medicine, Shenyang Agricultural University, Shenyang, Liaoning Province 110866, China

Full list of author information is available at the end of the article
}

of these animals, such as sheep, goat, cow, pig, chicken and horse [8]. Horse meat and donkey meat are also important foodstuff worldwide, and humans can acquire infections with $T$. gondii by ingesting raw or undercooked horse and donkey meat containing tissue cysts.

In equids, $T$. gondii infections generally display a subclinical course, and serological techniques for the detection of specific antibodies produced in the body against the parasite have a great diagnostic value [8]. Serum antibodies to $T$. gondii have been found in horses and donkeys in many surveys worldwide [8]. Table 1 summarizes the reports of $T$. gondii infection in horses and donkeys from China because these papers were published in the Chinese language in local journals and are not easily accessible to foreign scholars. In view of this background, the objective of this study was to survey the seroprevalence of $T$. gondii infection in horses and donkeys in Liaoning province, northeastern China.

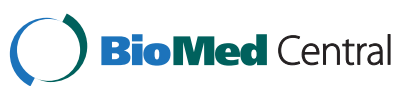


Table 1 Seroprevalence of $T$. gondii infection in horses and donkeys from China

\begin{tabular}{|c|c|c|c|c|c|c|}
\hline Province & Animal & No. tested & Positive(\%) & Method & Year of sampling & Reference \\
\hline Xinjiang & $\begin{array}{l}\text { Horse } \\
\text { Donkey }\end{array}$ & $\begin{array}{l}60 \\
30\end{array}$ & $\begin{array}{l}0(0) \\
0(0)\end{array}$ & $\begin{array}{l}\mathrm{HA} \\
\mathrm{HA}\end{array}$ & $<2002$ & [9] \\
\hline Hebei & $\begin{array}{l}\text { Horse } \\
\text { Donkey }\end{array}$ & $\begin{array}{l}65 \\
133\end{array}$ & $\begin{array}{l}4(6.2) \\
8(8.6)\end{array}$ & $\begin{array}{l}\text { ELISA } \\
\text { ELISA }\end{array}$ & $2000-2001$ & [10] \\
\hline Shandong & $\begin{array}{l}\text { Horse } \\
\text { Donkey }\end{array}$ & $\begin{array}{l}147 \\
17\end{array}$ & $\begin{array}{l}0(0) \\
1(5.9)\end{array}$ & $\begin{array}{l}\mathrm{IHA} \\
\mathrm{IHA}\end{array}$ & $<2001$ & [11] \\
\hline Qinghai & $\begin{array}{l}\text { Horse } \\
\text { Horse }\end{array}$ & $\begin{array}{l}149 \\
314\end{array}$ & $\begin{array}{l}4(2.7) \\
19(6.1)\end{array}$ & $\begin{array}{l}\text { IHA } \\
\text { IHA }\end{array}$ & $\begin{array}{l}<2008 \\
2010\end{array}$ & $\begin{array}{l}{[12]} \\
{[13]}\end{array}$ \\
\hline
\end{tabular}

\section{Methods}

\section{The study area}

Liaoning province is located in northeastern China, its geographical position is at east longitude $118^{\circ} 50^{\prime}-125^{\circ}$ $47^{\prime}$ and at north latitude $38^{\circ} 43^{\prime}-43^{\circ} 29^{\prime}$. It has an area of $145,900 \mathrm{~km}^{2}$ and a population of approximately 44 million. The area has a temperate monsoon climate with abundant sunshine, a long winter, hot summer, a short spring and autumn. The annual average temperature is $7-11^{\circ} \mathrm{C}$, with a highest temperature of $40^{\circ} \mathrm{C}$ and a lowest temperature of $-30^{\circ} \mathrm{C}$.

\section{Blood samples}

Blood samples were collected from 711 and 738 slaughtered horses and donkeys, respectively, in 13 regions of Liaoning province, including Shenyang, Dalian, Anshan, Fushun, Benxi, Dandong, Jinzhou, Yingkou, Fuxin, Liaoyang, Panjin, Chaoyang, and Huludao between May and October 2012. Horses were $>10$-yr-old, 39 (21.9\%) were female and 139 (78.1\%) were male; and donkeys were approximately 1-yr-old, 21 (12.1\%) were female and 153 (87.9\%) were male. These equids fed on forage, and most of these equids had outdoor access. The information was obtained via personal interviews with the veterinarians and owners. Serum samples were separated and stored at $-20^{\circ} \mathrm{C}$ until use.

\section{Serological examination}

Sera were tested for $T$. gondii antibodies using 2-fold serial dilutions from 1:25 to 1:3,200 with the modified agglutination test (MAT), as described previously [14]. Briefly, the harvested parasites were kept in $6 \%$ formaldehyde solution at $4^{\circ} \mathrm{C}$ overnight, and suspended in the alkaline buffer at 20,000 parasites/mL. Two-fold dilutions of sera were performed using the serum diluting buffer, and agglutination was performed in U-bottom 96-well microtiter plates using a mixture of $50 \mu \mathrm{L}$ antigen and $50 \mu \mathrm{L}$ diluted sera. The plates were incubated at $37^{\circ} \mathrm{C}$ overnight. The test was considered positive when a layer of agglutinated parasites was formed in wells at dilutions of 1:25 or higher; positive and negative controls were included in each test.

\section{Statistical analysis}

Statistical analysis of $T$. gondii seroprevalence between horse and donkey was performed using a Chi square test with SPSS (SPSS Inc., Chicago, Illinois). A $P$-value $<0.05$ was considered statistically significant.

\section{Ethics statement}

All animals were handled in strict accordance with good animal practice according to the Animal Ethics Procedures and Guidelines of the People's Republic of China, and the study was approved by the Animal Ethics Committee of Shenyang Agricultural University (Permit No. SYXK $<$ Liao $>$ 2011-0001).

\section{Results and discussion}

In the present study, 178 of 711 (25.0\%) horses were seropositive for $T$. gondii, with titers of 1:25 in 81, 1:50 in 62, 1:100 in 33, and 1:200 in 2 (Table 2), and seroprevalence of $T$. gondii infection from 13 regions ranged from $8.2 \%$ to $37.0 \%$ (Table 3). Antibodies to T. gondii were found in 174 of 738 (23.6\%) donkeys, with titers of 1:25 in 66, 1:50 in 54, 1:100 in 49, and 1:200 in 5 (Table 2). Among these positive donkeys, seroprevalence varied in 13 different regions, ranging from $9.1 \%$ to $32.6 \%$ (Table 3). There was no significant difference between horse and donkey in Liaoning province $(\mathrm{P}>0.05)$.

Some serological tests, including the Sabin-Feldman dye test (DT), latex agglutination test (LAT), indirect hemagglutination (IHA), indirect fluorescent antibody (IFA), enzyme-linked immunoabsorbent assay (ELISA), and modified agglutination test (MAT), have been used to detect T. gondii antibodies in equids; the latter (MAT) is both

Table 2 Antibody titers of $T$. gondii infection in horses and donkeys in Liaoning province, northeastern China by modified agglutination test (MAT)

\begin{tabular}{lccccc}
\hline & \multicolumn{5}{c}{ No. of sera with MAT in different titers } \\
\cline { 2 - 6 } Animal & $\mathbf{1 : 2 5}$ & $\mathbf{1 : 5 0}$ & $\mathbf{1 : 1 0 0}$ & $\mathbf{1 : 2 0 0}$ & $\mathbf{2 1 : 2 5}$ \\
\hline Horse & 81 & 62 & 33 & 2 & 178 \\
Donkey & 66 & 54 & 49 & 5 & 174 \\
Total & 147 & 116 & 82 & 7 & 352 \\
\hline
\end{tabular}


Table 3 The seroprevalence of $T$. gondii infection in horses and donkeys in Liaoning province, northeastern China

\begin{tabular}{lcccc}
\hline Region & \multicolumn{2}{c}{ Dorse } & \multicolumn{2}{c}{ Donkey } \\
\cline { 2 - 5 } & No. of sample & No. of positive (\%) & No. of sample & No. of positive (\%) \\
\hline Shenyang & 48 & $15(31.3)$ & 46 & $17(30.4)$ \\
Dalian & 52 & $13(25.0)$ & 50 & $11(22.9)$ \\
Anshan & 70 & $18(25.7)$ & 64 & $13(26.0)$ \\
Fushun & 61 & $17(27.9)$ & 46 & $19(29.7)$ \\
Benxi & 54 & $20(37.0)$ & 71 & $15(32.6)$ \\
Dandong & 68 & $11(16.2)$ & 68 & $12(16.9)$ \\
Jinzhou & 55 & $7(12.7)$ & 52 & $10(14.7)$ \\
Yingkou & 40 & $13(32.5)$ & 76 & $15(28.8)$ \\
Fuxin & 78 & $22(28.2)$ & 48 & $19(25.0)$ \\
Liaoyang & 58 & $19(32.7)$ & 62 & $15(31.3)$ \\
Panjin & 45 & $15(33.3)$ & 42 & $17(27.4)$ \\
Chaoyang & 33 & $4(12.1)$ & 55 & $6(14.3)$ \\
Huludao & 49 & $4(8.2)$ & 738 & $5(9.1)$ \\
Total & 711 & $178(25.0)$ & $174(23.6)$ \\
\hline
\end{tabular}

sensitive and specific [8]. Worldwide seroprevalence of T. gondii infection in horses has been summarised prior to 2010 by Dubey, ranging from $0.4 \%$ to $48.1 \%$ [8]; and since then, it has been reported to be $24 \%$ in the Czech Republic by LAT [15], 32\% in Riyadh Province, Saudi Arabia by DT [16], 34.0\% in Costa Rica by MAT [17], 69.6\% in the Fernando de Noronha, Brazil by MAT [18], and 10.8\% in Southern Spain by MAT [19]. Worldwide seroprevalence of $T$. gondii infection in donkeys was reported as $65.6 \%$ in Egypt by ELISA [8], 11.0\% in Gemlik, Turkey by LAT [8], 25.6\% in Southern Spain by MAT [19], and $43.2 \%$ in Northeast of Brazil by indirect immunofluorescence reaction (IFI) [20].

In China, some surveys have previously reported prevalence of $T$. gondii infection in horses and donkeys (Table 1), however, it is difficult to compare results of the present study with other surveys in China because of different serological tests used and due to the different regions of China studied. Most surveys used the IHA test, and one survey used ELISA. In this study, we used the MAT for the detection of T. gondii seroprevalence in horses and donkeys because it is the major recommended test for diagnosis of $T$. gondii infection in several animals and man $[8,14]$. MAT has high sensitivity and specificity among all serologic methods, and this method is cheaper, easier than other tests and does not need special sophisticated equipment [21,22]. In addition, many surveys in China were conducted many years ago.

In this study, we found that equids with outdoor access may have a greater chance of being exposed to the food and water contaminated with $T$. gondii oocysts, which had been excreted in feces by cats and might be present in forage and water. This is the reason that seroprevalence of $T$. gondii infection in equids was relatively high in the present study.

Results of the present study indicated that $T$. gondii infection is common in horses and donkeys in Liaoning province, and the parasite will remain present in their tissues for life. Horse meat and donkey meat were mostly consumed by local people. Therefore, animals such as horse and donkey are at a high risk of infection and act as a transmission route to humans. Further research on the role of equid meat in human infections and the pathogenesis of $T$. gondii is needed.

In this study, the seroprevalence results of $T$. gondii infection in equids were higher than other food animals, including pig, cattle, sheep, chicken, duck, and goose in Liaoning province, northeasern China (Table 4) [22-24]. These results also confirm that $T$. gondii infection in food animals is widespread in northeastern China and should be of public health concern.

Table 4 The seroprevalence of $T$. gondii infection in other food animals, including pig, cattle, sheep, chicken, duck, and goose in Liaoning province, northeastern China

\begin{tabular}{lcccc}
\hline Animal & No. of sample & No. of positive (\%) & Method & Reference \\
\hline Pig & 1164 & $140(12.0)$ & IHA & {$[23]$} \\
cattle & 646 & $39(6.0)$ & IHA & {$[23]$} \\
sheep & 566 & $25(4.4)$ & IHA & {$[24]$} \\
chicken & 502 & $37(5.8)$ & MAT & {$[22]$} \\
duck & 268 & $26(7.8)$ & MAT & {$[22]$} \\
goose & 128 & $9(4.7)$ & MAT & {$[22]$} \\
\hline
\end{tabular}




\section{Conclusions}

The results of the present study indicated that the rate of infection with $T$. gondii in horses and donkeys is a little high in Liaoning province, northeastern China, which suggests that consumption of horse and donkey meat in this area may represent a potential source for human infection with $T$. gondii. Therefore, it is necessary to take integrated strategies, including efficient management measures to prevent and control T. gondii infection in horses and donkeys, which would help to reduce T. gondii infection in humans.

\section{Competing interests}

The authors declare that they have no competing interests.

\section{Authors' contributions}

JBH and NY conceived and designed the study, and critically revised the manuscript. NY, MYM, GMY, GXZ and HKL performed the experiments, analysed the data and drafted the manuscript. All authors read and approved the final manuscript.

\section{Acknowledgements}

This study was supported by The National Natural Science Foundation of China (NSFC, Grant No. 31201894). The authors thank Dr. Isabelle Villena, Laboratoire de Parasitologie-Mycologie, Centre National de Référence de la Toxoplasmose, Centre de Ressources Biologiques Toxoplasma, Reims, France for providing the Toxoplasma gondii MAT antigen.

\section{Author details}

${ }^{1}$ College of Animal Science and Veterinary Medicine, Shenyang Agricultural University, Shenyang, Liaoning Province 110866, China. ${ }^{2}$ Liaoning Center for Animal Disease Control and Prevention, Shenyang, Liaoning Province 110164, China.

Received: 22 April 2013 Accepted: 11 May 2013

Published: 16 May 2013

\section{References}

1. Dubey JP: History of the discovery of the life cycle of Toxoplasma gondii. Int J Parasitol 2009, 39:877-882.

2. Montoya JG, Liesenfeld O: Toxoplasmosis. Lancet 2004, 363:1965-1976.

3. Yuan ZG, Gao SY, Liu Q, Xia XZ, Liu XF, Liu B, Hu RL: Toxoplasma gondii antibodies in cancer patients. Cancer Letters 2007, 254:71-74.

4. Alvarado-esquivel C, Torres-castorena A, Liesenfeld O, Garcia-lopez CR, Estrada-martinez S, Sifuentes-alvarez A, Marsal-hernandez JF, Esquivel-cruz R, Sandoval-herrera F, Castaneda JA, Dubey JP: Seroepidemiology of Toxoplasma gondii infection in pregnant women in rural Durango, Mexico. J Parasitol 2009, 95:271-274

5. Liu Q, Wei F, Gao SY, Jiang L, Lian H, Yuan B, Yuan ZG, Xia ZP, Liu B, Xu XH, Zhu XQ: Toxoplasma gondii infection in pregnant women in China. T Roy Soc Trop Med H 2009, 103:162-166.

6. Wu SM, Huang SY, Fu BQ, Liu GY, Chen JX, Chen MX, Yuan ZG, Zhou DH, Weng YB, Zhu XQ, Ye DH: Seroprevalence of Toxoplasma gondii infection in pet dogs in Lanzhou, Northwest China. Parasit Vectors 2011, 4:64.

7. Kijlstra A, Jongert E: Control of the risk of human toxoplasmosis transmitted by meat. Int J Parasitol 2008, 38:1359-1370.

8. Dubey JP: Toxoplasmosis of animals and humans. Secondth edition. Boca Raton, Florida, New York: CRC Press Inc; 2010:1-313.

9. Bai WS, Chen Y, Ba LT, Mai MT: Survey of Toxoplasma gondii infection in livestock in Aksu. Chin J Vet Parasitol 2002, 10:29-30 (in Chinese).

10. Yuan WY, Ma K, Yang HL: Survey of Toxoplasma gondii infections in animals in Hebei province. Chin J Schisto Control 2004, 16:72-73 (in Chinese).

11. Zhao YQ, Zhen TM, Wang JX, Fu B, Han GD: Survey of Toxoplasma gondii infections in animals in Shandong province. J Prev Med Inform 2001, 17:185 (in Chinese).
12. Chen CY: Seroprevalence of Toxoplasma gondii infections in livestock in Datong county. Chin Qinghai J Ani Vet Sci 2008, $38: 23$ (in Chinese).

13. Ma GB, Ma LQ, Wang GP, Lu Y, Cai QG, Ye CY, Niu XY: Serological test of toxoplasmosis in animals in Qinghai province. Chin Qinghai J Ani Vet Sci 2011, 41:25-26 (in Chinese).

14. Dubey JP, Desmonts G: Serological responses of equids fed Toxoplasma gondii oocysts. Equine Vet J 1987, 19:337-339.

15. Bártová E, Sedlák K, Syrová M, Literák I: Neospora spp. and Toxoplasma gondii antibodies in horses in the Czech Republic. Parasitol Res 2010, 107:783-785.

16. Alanazi AD, Alyousif MS: Prevalence of antibodies to Toxoplasma gondii in horses in Riyadh Province, Saudi Arabia. J Parasitol 2011, 97:943-945.

17. Dangoudoubiyam S, Oliveira JB, Víquez C, Gómez-García A, González O, Romero JJ, Kwok OCH, Dubey JP, Howe DK: Detection of antibodies against Sarcocystis neurona, Neospora spp., and Toxoplasma gondii in horses from Costa Rica. J Parasitol 2011, 97:522-524.

18. Costa DG, Marvulo MF, Silva JS, Santana SC, Magalhães FJ, Filho CD, Ribeiro VO, Alves LC, Mota RA, Dubey JP, Silva JC: Seroprevalence of Toxoplasma gondii in domestic and wild animals from the Fernando de Noronha, Brazil. J Parasitol 2012, 98:679-680.

19. García-Bocanegra I, Cabezón O, Arenas-Montes A, Carbonero A, Dubey JP, Perea A, Almería S: Seroprevalence of Toxoplasma gondii in equids from southern Spain. Parasitol Int 2012, 61:421-424.

20. Oliveira E, Albuquerque PPF, Souza Neto OL, Faria EB, Júnior JWP, Mota RA: Occurrence of antibodies to Toxoplasma gondii in mules and donkeys in the northeast of Brazil. J Parasitol 2013, 99:343-345.

21. Cong W, Huang SY, Zhou DH, Xu MJ, Wu SM, Yan C, Zhao Q, Song HQ, Zhu XQ: First report of Toxoplasma gondii infection in market-sold adult chickens, ducks and pigeons in northwest China. Parasit Vectors 2012, 5:110.

22. Yang N, Mu MY, Li HK, Long M, He JB: Seroprevalence of Toxoplasma gondii infection in slaughtered chickens, ducks, and geese in Shenyang, northeastern China. Parasit Vectors 2012, 5:237.

23. Liu XJ, Liu CW, Liu YJ, Jin HT, Zhao YK, Chen J, Yang M, Liu Q: Seroprevalence of Toxoplasma gondii infection in slaughtered pigs and cattle in Liaoning province, northeastern China. J Parasitol 2012, 98:440-441.

24. Yang N, Li HK, He JB, Mu MY, Yang SH: Seroprevalence of Toxoplasma gondii infection in domestic sheep in Liaoning province, northeastern China. J Parasitol 2013, 99:174-175.

doi:10.1186/1756-3305-6-140

Cite this article as: Yang et al: Seroprevalence of Toxoplasma gondii in slaughtered horses and donkeys in Liaoning province, northeastern China. Parasites \& Vectors 2013 6:140.

\section{Submit your next manuscript to BioMed Central and take full advantage of:}

- Convenient online submission

- Thorough peer review

- No space constraints or color figure charges

- Immediate publication on acceptance

- Inclusion in PubMed, CAS, Scopus and Google Scholar

- Research which is freely available for redistribution 